\title{
KEPENTINGAN KEBERADAAN PENGEPUL DAN KEPUASAN PETANI AKAN KINERJANYA SEBAGAI AGEN PEMASAR MALAI PANDANWANGI
}

\author{
Oleh: \\ Endah Lisarini*) \\ Siti Nur Ilah Adillah**)
}

\begin{abstract}
Abstrak
Sebagian besar petani skala kecil di Indonesia masih bergantung pada tengkulak atau pengepul untuk memasarkan hasil pertaniannya. Sementara kebijakan-kebijakan di pertanian mengarah kepada pemutusan rantai pemasaran yang panjang termasuk menghilangkan keberadaan tengkulak dan pengepul. Kondisi yang kontradiktif ini memotivasi dilakukannya penelitian dengan tujuan untuk mengkaji : 1) berbagai manfaat pengepul bagi petani; 2) tingkat kepentingan kinerja pengepul bagi petani; 3) tingkat kepuasan petani akan kinerja pengepul. Penelitian dilakukan dengan melibatkan 35 responden petani padi Pandanwangi yang menjual malainya ke pengepul. Responden petani mempunyai karakteristik : didominasi oleh petani laki-laki, berusia di atas 50 tahun, berpendidikan sekolah dasar (SD), sudah berprofesi sebagai petani lebih dari 15 tahun dengan luas garapan lahan rata-rata- satu hektar. Jumlah populasi petani tidak diketahui dengan pasti, maka penentuan responden sebagai sampel dilakukan dengan metode non probability sampling dan teknik purposive sampling. Tingkat kepentingan dan tingkat kepuasan petani akan keberadaan dan kinerja pengepul merupakan variabel penelitian yang dikaji menggunakan metode analisis Index Performance Analysis (IPA) dan Customer Satisfaction Index (CSI). Diperoleh hasil penelitian yang menyimpulkan: 1) Keberadaan pengepul masih dibutuhkan petani karena memberi manfaat antara lain menerima pasokan malai Pandanwangi dalam jumlah berapapun dan dalam kondisi mutu apapun, menanggung biaya-biaya pemasaram dan terkadang menyediakan modal kerja; 2) kinerja pengepul bagi petani dianggap penting dengan skor rata-rata tingkat kepentingan sebesar 4.14 (skala 1 - 5); dan 3) petani merasa puas dengan kinerja pengepul sebagai agen pemasar dengan skor rata-rata tingkat kepuasan 3.79 (skala 1 - 5) atau dikategorikan puas sebesar 76\% $(66 \%<$ CSI $\leq 80 \%)$. Dari hasil penelitian ini menjelaskan bahwa keberadaan pengepul masih diperlukan bagi petani dengan luas lahan garapan relative sempit dan terbatas modal usahataninya. Agar petani tidak terlalu lemah daya tawar harga malai Pandanwangi, para petani perlu bergabung ke dalam kelompok tani.
\end{abstract}

Kata kunci : Malai Pandanwangi, Pengepul, Agen pemasar.

\begin{abstract}
Most of the small scale farmers in Indonesia still depend on middlemen or collectors to market their agricultural products. Meanwbile, policies in agriculture lead to breaking the long marketing chain, including eliminating the existence of middlemen and collectors. These contradictory conditions motivate research with the aim of examining: 1) the various benefits of collectors for farmers; 2) the level of importance of the performance of collectors for farmers; 3) the level of farmer satisfaction with the performance of the collectors. The study was conducted by involving 35 respondents of Pandanwangi rice farmers who sold their panicles to collectors. Respondent farmers have characteristics: dominated by male farmers, aged over 50 years, educated in elementary school (SD), bave worked as farmers for more than 15 years with an average cultivated area of
\end{abstract}


one hectare. The number of farmer population is not known with certainty, so the determination of respondents as a sample was carried out using non-probability sampling methods and purposive sampling techniques. The level of importance and level of farmer satisfaction with the existence and performance of collectors are research variables that are studied using the Index Performance Analysis (IPA) and Customer Satisfaction Index (CSI) analysis methods. The results of the research concluded that: 1) The existence of collectors is still needed by farmers because they provide benefits, among others, receiving supplies of Pandanwangi panicles in any amount and under any quality condition, bearing marketing costs and sometimes providing working capital; 2) the performance of collectors for farmers is considered important with an average score of 4.14 (scale of 1 - 5); and 3) farmers are satisfied with the performance of collectors as marketing agents with an average score of 3.79 (scale 1 - 5) or categorized as satisfied by $76 \%(66 \%<$ CSI $\leq 80 \%$ ). From the results of this study, it is explained that the existence of collectors is still needed for farmers with relatively narrow cultivated land and limited farming capital. So that farmers do not have too weak bargaining power in the price of Pandanwangi panicles, farmers need to join the farmer groups.

Key words : Panicles of Pandanwangi, Collectors, Marketing agents.

*) Dosen Fakultas Sains Terapan UNSUR.

**) Alumni Fakultas Sains Terapan UNSUR. 


\section{PENDAHULUAN}

Padi merupakan tanaman pangan utama yang telah dibudidayakan sejak lama oleh para petani Indonesia. Sistem distribusi gabah dan beras pun telah dan terus menerus diperbaiki oleh pemerintah hingga bermunculan adanya lumbung padi atau resi gudang dan lembaga Bulog serta kebijakan - kebijakan yang mengatur distribusi beras. Hal tersebut tidak menghentikan aktivitas tengkulak atau penebas, pengepul, makelar, penggiling, pedagang beras dan agen pemasar lainnya dalam rantai pasok padi mulai dari pembelian gabah di lahan sampai masuk ke penggilingan gabah hingga beras sampai ke konsumen. Keberadaan pengepul dan agen pemasar lainnya masih dibutuhkan oleh para petani padi dengan luas garapan kurang dari satu hektar (Azizah, 2016; Megasari, 2018). Panjangnya rantai distribusi inilah yang menyebabkan terjadinya disparitas harga gabah di tingkat petani dengan harga beras di tingkat konsumen. Disparitas harga juga terjadi pada padi Pandanwangi. Padi Pandanwangi sebagai padi Indikasi Geografis dan diklasifikasikan ke dalam beras kelas mutu khusus (Permentan, 2017) mempunyai karakteristik gabahnya berekor dan tidak mudah dirontokkan (Patiwiri, 2006). Untuk menjadi beras, malai padi Pandanwangi mengalami proses yang cukup panjang. Seluruh biaya penanganan pasca panen padi Pandanwangi sampai menjadi beras cukup besar. Bagi para petani, hal ini cukup memberatkan. Oleh karena itu tengkulak atau pengepul membeli gabah Pandanwangi berupa malai. Pengepullah yang akan menanggung biaya-biaya penangan pasca panen.

Pengepul sebagai agen pemasar malai Pandanwangi pada umumnya mempunyai mesin perontok malai dan penggiling gabah. Keberadaannya diperlukan bagi petani, selain sebagai pembeli gabah atau malai, pengepul juga memberikan bantuan pinjaman modal usahatani (Megasari, 2018). Dengan adanya bantuan modal, akses informasi pasar dan jejaring pasar, pengepul menciptakan ketergantungan petani padanya (Azizah, 2016; Megasari, 2018). Walaupun petani membutuhkan keberadaan pengepul, belum diketahui seberapa penting dan seberapa puas petani merasakan layanan yang diberikan oleh pengepul. Berdasarkan keadaan tersebut, dilakukan penelitian pada bulan April - Juli 2019 dengan tujuan mengkaji : 1) berbagai manfaat pengepul bagi petani; 2) tingkat kepentingan kinerja pengepul bagi petani; 3) tingkat kepuasan petani akan kinerja pengepul. Kepuasan petani terhadap kinerja pengepul terpenuhi apabila harapan petani sesuai dengan yang diterimanya dari pengepul dan harapan petani dapat dijadikan patokan minimal dalam menilai kinerja pengepul. Hal ini sesuai dengan sejumlah teori dan konsep kepuasan (Irawan dkk, 2017; Ferdinanda, 2016; Tjiptono et al, 2000). Kepuasan dapat ditujukan terhadap suatu produk, kinerja dan layanan. Kinerja merupakan hasil suatu pekerjaan atau capaian prestasi kerja (Wibowo, 2007). Kepentingan merupakan dasar dari timbulnya tingkah laku individu atau kelompok untuk memenuhi keperluan atau kebutuhannya. Tingkat kepentingan bagi orang yang menerima layanan menunjukkan tingkat kualitas kinerja layanan yang diterimanya. Pada akhirnya tingkat kepentingan dan kualitas kinerja layanan akan menentukan tingkat kepuasan pihak yang dilayani (Setiawati dkk, 2008).

\section{METODE PENELITIAN}

Untuk menjawab tujuan penelitian pertama, dilakukan observasi dan wawancara kepada 10 orang petani dari 35 petani responden yang ditentukan secara acak sederhana. Analisis data dilakukan secara deskriptif kualitatif. Sementara untuk menjawab tujuan penelitian ke dua dan ke tiga dilakukan metode analisis IPA dan CSI (Aritonang, 2005) untuk mendapatkan tingkat kepentingan dan tingkat kepuasan petani pemasok malai Pandanwangi kepada para pengepul sebagai agen pemasar. Data dikumpulkan 
melalui kuesioner yang diberikan kepada 35 petani yang menjual malai Pandanwanginya kepada pengepul dengan teknik sampling non probability purposive sampling.

Variabel yang dikaji dalam penelitian ini meliputi : kinerja pengepul, kepentingan dan kepuasan petani. Tanggapan responden berupa jawaban dengan interval dari Sangat Penting / Sangat Baik / Sangat Puas (skala 5) sampai Sangat Tidak Penting / Sangat Tidak Baik / Sangat Tidak Puas (skala 1). Berturut-turut Tabel Skala Tanggapan Responden dan Tabel Operasional Variabel Penelitian dapat dilihat pada
Tabel 1 dan Tabel 2. Kepuasan sangat berkaitan erat dengan kesesuaian antara layanan atau kinerja yang diharapkan dengan yang diterima (Tjiptono, 2011). Harapan dari pihak yang mendapatkan layanan tidak hanya pada kualitas layanannya saja melainkan juga pada kepentingan dari layanan tersebut. Oleh karena itu pada penelitian ini tingkat kepuasan petani diukur melalui kinerja atau layanan yang diberikan oleh pengepul sebagai pihak yang menerima pasokan malai Pandanwangi sekaligus sebagai agen pemasar. Skala ukur yang digunakan adalah skala interval seperti pada Tabel 1 .

Tabel 1. Skala tanggapan responden.

\begin{tabular}{clc}
\hline No. & \multicolumn{1}{c}{ Parameter } & Interval \\
\hline $\mathbf{1}$ & Sangat Penting / Sangat baik / Sangat Tidak Puas & $4.20-5.00$ \\
$\mathbf{2}$ & Penting / Baik / Puas & $3.40-4.19$ \\
$\mathbf{3}$ & Cukup Penting / Cukup Baik / Cukup Puas & $2.60-3.39$ \\
$\mathbf{4}$ & Tidak Penting / Tidak Baik / Tidak Puas & $1.80-2.59$ \\
$\mathbf{5}$ & Sangat Tidak Penting / Sangat Tidak Baik / Sangat Tidak Puas & $1.00-1.79$ \\
\hline
\end{tabular}

Tabel 2. Operasionalisasi variabel penelitian.

\begin{tabular}{|c|c|c|c|}
\hline $\begin{array}{l}\text { Variabel } \\
\text { Penelitian }\end{array}$ & Konsep variabel & Indikator Variabel & $\begin{array}{c}\text { Skala } \\
\text { Pengukuran }\end{array}$ \\
\hline Kinerja & $\begin{array}{l}\text { Menurut Amstrong dan Baron } \\
\text { (1998) dalam Abdullah (2014) } \\
\text { kinerja merupakan hasil } \\
\text { pekerjaan yang mempunyai } \\
\text { hubungan kuat dengan tujuan } \\
\text { strategi organisasi, kepuasan } \\
\text { konsumen dan memberikan } \\
\text { kontribusi ekonomi. }\end{array}$ & $\begin{array}{l}\text { 1. Penerimaan jumlah pasokan } \\
\text { Malai Pandanwangi. } \\
\text { 2. Penerimaan pasokan Malai } \\
\text { Pandanwangi dengan kualitas } \\
\text { apa pun. }\end{array}$ & Interval \\
\hline Kepentingan & $\begin{array}{l}\text { Kepentingan adalah } \\
\text { mendahulukan suatu kebutuhan } \\
\text { atau keperluan yang bersifat } \\
\text { lebih umum (Wibowo, 2007) }\end{array}$ & $\begin{array}{l}\text { 1. Penerimaan jumlah pasokan } \\
\text { Malai Pandanwangi. } \\
\text { 2. Penerimaan pasokan Malai } \\
\text { Pandanwangi dengan kualitas } \\
\text { apa pun. }\end{array}$ & Interval \\
\hline Kepuasan & $\begin{array}{l}\text { Menurut Kotler dalam Tjiptono } \\
\text { (2011) "kepuasan pelanggan } \\
\text { adalah tingkat perasaan } \\
\text { seseorang setelah } \\
\text { membandingkan kinerja (atau } \\
\text { hasil) yang dirasakan dibanding } \\
\text { dengan harapaan" }\end{array}$ & $\begin{array}{l}\text { 1. Kesesuaian layanan dalam } \\
\text { penerimaan jumlah pasokan } \\
\text { Malai Pandanwangi } \\
\text { 2. Kesesuaian layanan dalam } \\
\text { menggung produk yang tidak } \\
\text { memenuhi mutu. }\end{array}$ & Interval \\
\hline \multicolumn{2}{|c|}{ HASIL DAN PEMBAHASAN } & diperoleh dari 35 & tani padi \\
\hline $\begin{array}{l}\text { Data } \\
\text { tanggapan } \\
\text { kepuasannya }\end{array}$ & $\begin{array}{l}\text { hasil penelitian berupa } \\
\text { responden mengenai } \\
\text { terhadap kinerja pengepul }\end{array}$ & $\begin{array}{l}\text { seperti pada Tabel 3. Resp } \\
\text { layak memberikan tangg } \\
\text { responden merupakan }\end{array}$ & $\begin{array}{l}\text { nden dianggap } \\
\text { annya karena } \\
\text { petani padi }\end{array}$ \\
\hline
\end{tabular}


Pandanwangi yang sudah berpengalaman lebih dari 5 tahun walaupun luas lahan garapannya sebagian besar berkisar $1-2$ hektar. Dengan luas garapan $1-2$ hektar, petani cenderung menjual hasil panennya langsung ke pengepul. Alasan petani langsung menjual malainya ke pengepul karena petani tidak perlu lagi menanggung biaya-biaya penangan pasca panen dan transportasi. Usia petani yang sebagian besar di atas 50 tahun dan pada umumnya berpendidikan SD, membuatnya terbatas berhubungan dan berkomunikasi dengan pihak luar serta tidak memiliki akses pasar langsung. Keadaan demikian menjadikan mereka tergantung kepada pengepul. Karakteristik petani seperti itu mewakili gambaran petani pemilik sekaligus penggarap tradisional yang dalam usaha taninya dilakukan secara turun temurun.

Tabel 3. Karakteristik responden (petani padi pandanwangi).

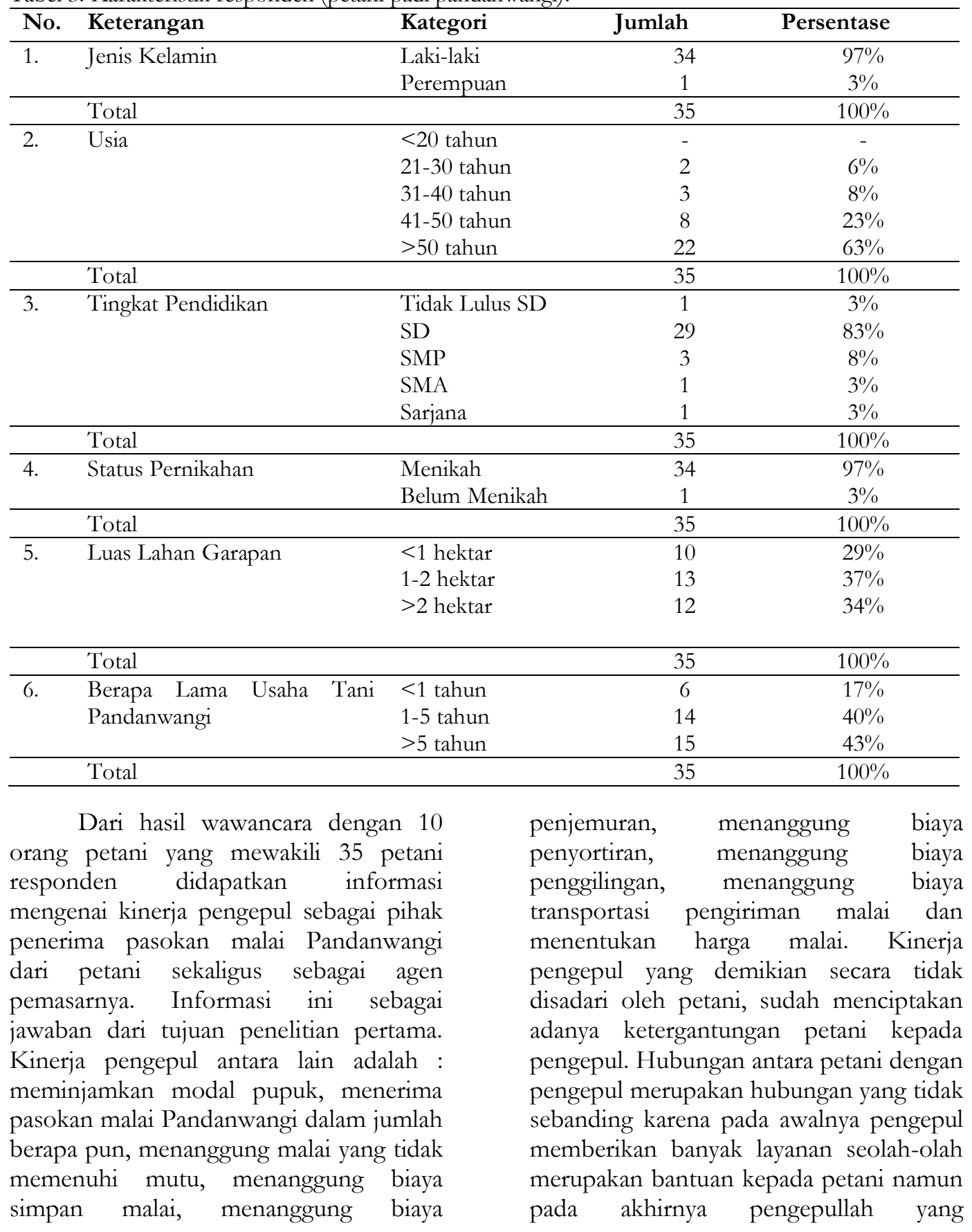


menentukan harga. Hal ini sesuai dengan sejumlah penelitian terdahulu mengenai ketergantungan petani kepada tengkulak dari Fuad dkk (2015); Hutabarat (2013).

Semua layanan yang diberikan pengepul berbeda-beda tingkat kepentingannya bagi para petani. Baik tidaknya kinerja atau layanan dapat menciptakan kepuasan (Chinomona et al.,2013 dan 2014). Kinerja yang sesuai dengan harapan petani memberikan kepuasan bagi petani, dan sebaliknya. Tingkat kepentingan dan tingkat kepuasan petani terhadap kinerja pengepul diukur melalui metode Index Performance Analysis dan Customer Satisfaction Index. Didapatkan hasil tanggapan responden mengenai tingkat kepentingan kinerja pengepul seperti yang ditunjukkan pada Tabel 4 .

Tabel 4. Tanggapan petani mengenai tingkat kepentingan kinerja pengepul

\begin{tabular}{|c|c|c|c|c|c|c|c|}
\hline No. & Pernyataan & 5 & 4 & 3 & 2 & 1 & Rata-Rata \\
\hline $\mathrm{I}_{1}$ & $\begin{array}{l}\text { Pengepul menerima jumlah pasokan malai } \\
\text { Pandanwangi }\end{array}$ & 34 & 1 & 0 & 0 & 0 & 4.97 \\
\hline $\mathrm{I}_{2}$ & Pengepul menanggung malai tidak memenuhi mutu & 13 & 19 & 3 & 0 & 0 & 4.26 \\
\hline $\mathrm{I}_{3}$ & $\begin{array}{l}\text { Pengepul mengembalikan malai yang tidak } \\
\text { memenuhi mutu }\end{array}$ & 0 & 2 & 14 & 19 & 0 & 2.54 \\
\hline $\mathrm{I}_{4}$ & Pengepul menanggung biaya simpan Malai & 7 & 25 & 3 & 0 & 0 & 4.11 \\
\hline $\mathrm{I}_{5}$ & $\begin{array}{l}\text { Pengepul menanggung biaya transportasi pengiriman } \\
\text { Malai }\end{array}$ & 17 & 18 & 0 & 0 & 0 & 4.49 \\
\hline $\mathrm{I}_{6}$ & Pengepul menanggung biaya penyortiran & 2 & 32 & 1 & 0 & 0 & 4.00 \\
\hline $\mathrm{I}_{7}$ & Pengepul menanggung biaya penggilingan & 4 & 30 & 1 & 0 & 0 & 4.06 \\
\hline $\mathrm{I}_{8}$ & Pengepul meminjamkan modal pupuk & 35 & 0 & 0 & 0 & 0 & 4.94 \\
\hline $\mathrm{I}_{9}$ & Pengepul menentukan harga malai & 4 & 25 & 6 & 0 & 0 & 3.94 \\
\hline $\mathrm{I}_{10}$ & Menanggung biaya penjemuran & 6 & 28 & 1 & 0 & 0 & 4.09 \\
\hline & Rata-rata & & & & & & 4.14 \\
\hline
\end{tabular}

Skor rata-rata tertinggi sebesar 4.94 adalah kinerja pengepul meminjamkan modal pupuk kepada petani pemasok malai. Kinerja ini dikategorikan sangat penting. Keadaan ini menunjukkan bahwa pada umumnya petani pemilik lahan relative sempit dan sekaligus sebagai penggarap lahannya, tetap membutuhkan bantuan dalam penyediaan modal khususnya untuk pembelian pupuk. Pupuk sebagai salah satu faktor produksi penting, oleh karena itu dengan meminjamkan modal untuk pembelian pupuk, secara tidak langsung pengepul semakin menciptakan ketergantungan petani kepadanya. Skor terendah sebesar 2.54 adalah kinerja pengepul yang dianggap tidak penting oleh petani yaitu pengepul mengembalikan malai yang tidak memenuhi mutu. Petani pada umumnya menginginkan malai diterima seluruhnya oleh pengepul dalam kondisi mutu apapun. Secara keseluruhan, kinerja pengepul dianggap penting oleh petani dengan skor rata-rata 4.14. Hal ini menunjukkan bahwa keberadaan pengepul masih dianggap penting baik sebagai penerima pasokan maupun sebagai agen pemasar.

Tanggapan petani mengenai baik tidaknya kinerja pengepul selama ini sebagai penerima pasokan sekaligus sebagai agen pemasar bagi petani, dapat dilihat pada Tabel 5. 
Tabel 5. Tanggapan responden terhadap baik tidaknya kinerja pengepul.

\begin{tabular}{|c|c|c|c|c|c|c|c|}
\hline No. & Pernyataan & 5 & 4 & 3 & 2 & 1 & Rata-Rata \\
\hline P1 & $\begin{array}{l}\text { Pengepul menerima jumlah pasokan } \\
\text { malai Pandanwangi }\end{array}$ & 25 & 10 & 0 & 0 & 0 & 4,71 \\
\hline P2 & $\begin{array}{l}\text { Pengepul menanggung malai tidak } \\
\text { memenuhi mutu }\end{array}$ & 12 & 22 & 1 & 0 & 0 & 4,31 \\
\hline P3 & $\begin{array}{l}\text { Pengepul mengembalikan malai yang } \\
\text { tidak memenuhi mutu }\end{array}$ & 2 & 16 & 17 & 0 & 0 & 3,60 \\
\hline P4 & $\begin{array}{l}\text { Pengepul menanggung biaya simpan } \\
\text { Malai }\end{array}$ & 4 & 24 & 6 & 1 & 0 & 3,86 \\
\hline P5 & $\begin{array}{l}\text { Pengepul menanggung biaya } \\
\text { transportasi pengiriman Malai }\end{array}$ & 2 & 20 & 11 & 2 & 0 & 3,60 \\
\hline P6 & $\begin{array}{l}\text { Pengepul menanggung biaya } \\
\text { penyortiran }\end{array}$ & 1 & 22 & 11 & 1 & 0 & 3,66 \\
\hline P7 & $\begin{array}{lll}\text { Pengepul menanggung } & \text { biaya } \\
\text { penggilingan } & & \end{array}$ & 1 & 22 & 11 & 1 & 0 & 3,66 \\
\hline P8 & Pengepul meminjamkan modal pupuk & 9 & 4 & 5 & 14 & 1 & 3,11 \\
\hline P9 & Pengepul menentukan harga malai & 2 & 22 & 11 & 0 & 0 & 3,66 \\
\hline P10 & Menanggung biaya penjemuran & 1 & 24 & 7 & 2 & 0 & 3,69 \\
\hline
\end{tabular}

Responden memberikan tanggapan tertinggi pada kinerja pengepul yang bersedia menerima pasokan malai dalam jumlah berapa pun. Kinerja pengepul dikategori sangat baik dengan skor 4.71 pada interval (4.20 - 5.00). Kinerja pengepul yang masih dikategorikan sangat baik adalah kinerja mau menerima malai dalam kondisi mutu apa pun dengan skor rata-rata 4.13. Kinerja pengepul lainnya ditanggapi baik $(3.40$ - 4.20) oleh responden dan hanya kinerja meminjamkan modal yang ditanggapi cukup baik $(2.60$ - 3.40) oleh responden. Kinerja pengepul lebih kepada menerima pasokan dan menanggung biaya pemasaran daripada meminjamkan modal. Secara keseluruhan, responden menanggapi kinerja pengepul baik karena petani sudah merasa terbantu dengan diterimanya pasokan dalam kuantitas berapa pun dan kualitas apa pun.

Untuk mengetahui lebih jauh tingkat kepuasan petani terhadap kinerja pengepul, dilakukan analisis CSI. CSI digunakan untuk menganalisis sejauh mana tingkat kepentingan dan tingkat kinerja atribut Agen Pemasar Malai Pandanwangi memberikan kepuasan pada petani. Hasil analisis CSI dapat dilihat pada Tabel 6. 
Tabel 6. Hasil perhitungan tingkat kepuasan ppetani terhadap kinerja pengepul dengan CSI

\begin{tabular}{|c|c|c|c|c|c|}
\hline No. & atribut & MIS & MSS & WF & WS \\
\hline $\mathbf{P 1}$ & $\begin{array}{l}\text { Pengepul menerima jumlah pasokan malai } \\
\text { Pandanwangi }\end{array}$ & 4,97 & 4,71 & 0,12 & 0,57 \\
\hline P2 & $\begin{array}{l}\text { Pengepul menanggung malai tidak } \\
\text { memenuhi mutu }\end{array}$ & 4,26 & 4,31 & 0,10 & 0,44 \\
\hline P3 & $\begin{array}{l}\text { Pengepul mengembalikan malai yang } \\
\text { tidak memenuhi mutu }\end{array}$ & 2,54 & 3,60 & 0,06 & 0,22 \\
\hline P4 & Pengepul menanggung biaya simpan Malai & 4,11 & 3,86 & 0,10 & 0,38 \\
\hline P5 & $\begin{array}{l}\text { Pengepul menanggung biaya transportasi } \\
\text { pengiriman Malai }\end{array}$ & 4,49 & 3,60 & 0,11 & 0,39 \\
\hline P6 & Pengepul menanggung biaya penyortiran & 4,00 & 3,66 & 0,10 & 0,35 \\
\hline P7 & Pengepul menanggung biaya penggilingan & 4,06 & 3,66 & 0,10 & 0,36 \\
\hline P8 & Pengepul meminjamkan modal pupuk & 4,94 & 3,11 & 0,12 & 0,37 \\
\hline P9 & Pengepul menentukan harga malai & 3,94 & 3,66 & 0,10 & 0,35 \\
\hline P10 & Menanggung biaya penjemuran & 4,09 & 3,69 & 0,10 & 0,36 \\
\hline & Total & 41,40 & \multicolumn{2}{|c|}{ Weight Total (WT) } & 3,80 \\
\hline & Costumer Satisfaction Index (CSI) & & & & $76,00 \%$ \\
\hline
\end{tabular}

Tingkat kepuasan petani terhadap kinerja pengepul sebesar $76 \%(66 \%<$ CSI $\leq 80 \%$ atau kategori puas. Untuk mengertahui hubungan antara tingkat kepuasan petani akan kinerja pengepul dengan tingkat kepentingan kinerja pengepul bagi petani, dapat diketahui melalui diagram kartesius. Pada akhirnya seluruh kinerja Pengepul dapat dikategorikan berdasarkan tingkat kepentingan dan kinerja pengepul ke dalam empat kategori atau kuadran yaitu : kuadran I disebut kuadran prioritas utama, kuadran II disebut kuadran pertahankan prestasi, kuadran III prioritas rendah dan kuadran IV merupakan kuadran 'berlebihan. Masing-masing kategori kinerja Pengepul tersaji pada diagram kartesius Gambar 1.

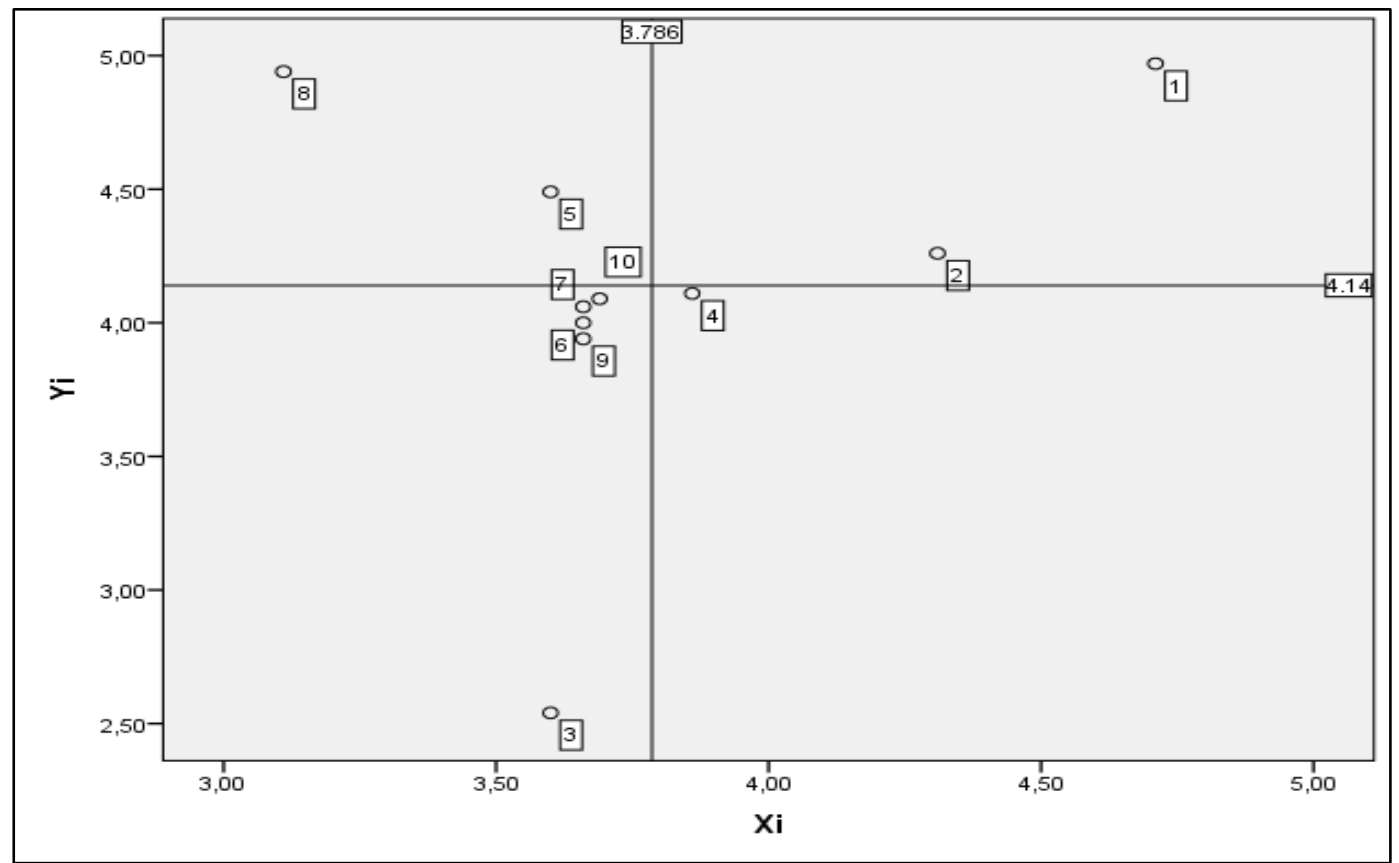

Gambar 1. Diagram Kartesius kinerja Pengepul malai Pandanwangi $\left(\mathrm{X}_{\mathrm{i}}\right.$ : Kinerja, $\mathrm{Y}_{\mathrm{i}}$ : Kepentingan). 


\section{Kuadran I Prioritas Utama}

Kinerja yang berada pada kuadran ini dianggap sangat penting oleh petani tetapi pelayanannya masih dirasa kurang memuaskan. Ada dua kinerja yang berada di kuadran ini yaitu kinerja pengepul menanggung biaya transportasi pengiriman malai dan kinerja meminjamkan modal. Dua kinerja ini dianggap sangat penting oleh petani karena petani sangat membutuhkan peran dari agen pemasar untuk menanggung biaya transportasi pengiriman malai serta membutuhkan peran agen pemasar untuk memberikan pinjaman modal. Petani merasa kinerja pengepul belum memberikan kepuasan karena petani belum mendapatkan apa yanng diharapkan. Karena kinerja pengepul dalam hal ini dianggap sangat penting namun belum memberikan kepuasan bagi petani, maka pengepul dapat meningkatkan perannya dengan cara melibatkan petani dalam pengambilan keputusan yang berkaitan dengan peminjjaman modal.

\section{Kuadran II Pertahankan Prestasi}

Kinerja yang berada pada kuadran ini dianggap sangat penting oleh petani dan dirasakan sangat memuaskan. Kinerja tersebut yaitu pengepul menerima jumlah pasokan malai Pandanwangi dan pengepul menanggung malai yang tidak memenuhi mutu. Kinerja yang termasuk dalam kuadran ini selayaknya dipertahankan karena kinerja ini yang diharapkan oleh petani.

\section{Kuadran III Prioritas Rendah}

Kinerja yang berada pada kuadran ini dianggap tidak terlalu penting oleh petani dan pelayanannya kurang memuaskan seperti pengepul mengembalikan malai yang tidak memenuhi mutu, pengepul menanggung biaya penggilingan, pengepul menanggung biaya penyortiran, pengepul menentukan harga malai dan pengepul menanggung biaya penjemuran. Kinerja ini dianggap kurang penting karena segala yang ditanggung pengepul merupakan biaya- biaya pemasaran yang selayaknya ditanggung oleh agen pemasar.

\section{Kuadran IV Berlebihan}

Kinerja yang berada pada kuadran ini dianggap tidak terlalu penting oleh petani namun pelayanannya justru memberikan kepuasan. Kinerja tersebut yaitu pengepul menanggung biaya simpan malai. Hal ini dapat menjadi nilai tambah bagi agen pemasar karena petani merasa terbantu dalam penyimpanan malai sebelum digiling menjadi beras.

\section{KESIMPULAN}

Dari pembahasan hasil penelitian di atas, dapat disimpulkan beberapa hal berikut :

1. Manfaat pengepul bagi petani pemasok adalah kinerjanya dalam meminjamkan modal pupuk, menerima pasokan malai Pandanwangi dalam jumlah berapa pun, menanggung malai yang tidak memenuhi mutu, menanggung biaya simpan malai, menanggung biaya penjemuran, menanggung biaya penyortiran, menanggung biaya penggilingan, menanggung biaya transportasi pengiriman malai dan menentukan harga malai.

2. Keberadaan pengepul sebagai agen pemasar dianggap penting oleh petani pemasok karena pengepul benar-benar membantu petani dalam memasarkan malainya.

3. Kinerja pengepul sebagai agen pemasar dirasakan memuaskan bagi petani pemasok karena sebagian besar kinerja pengepul sudah sesuai harapan petani.

\section{DAFTAR PUSTAKA}

Abdullah, M. 2014. Manajemen Dan Evaluasi Kinerja Karyawan. B.R. Hakin editin. Aswaja Presindo. Yokyakarta.

Aritonang, Lerbin. R. 2005. Kepuasan Pelanggan. P.T. Gramedia Pustaka Utama. Jakarta.

Azizah, Elfrida Nurul. 2016. Peran Positif Tengkulak Dalam Pemasaran Buah Manggis Petani : Studi Jaringan 
Sosial Tengkulak Di Desa Karacak, Kecamatan Leuwiliang, Kabupaten Bogor; Indonesian Journal of Sociology and Education Policy. Hal: 81 - 102. Bogor.

Chinomona, R. and M. Sandada. 2013. "Customer Satisfaction, Trust and Loyalty as Predictor Customer Intention to Re-purchase South African Retailling Industry". Mediterranean Journal of Social Sciences. 4 (14): pp- 437.

and Dorah Dubihlela. 2014.

"Does Customer Satisfaction Lead to Customer Trust, Loyalty and Repurchace Intention of Local Store Brand. The Case of Gauteng Provice South Africa". Mediterranean Journal of Social Sciences. 5(9): p:23.

Ferdinanda. 2016. Analisis Kinerja Pelayanan dan Persepsi Pengunjung Museum Ullen Sentalu Dengan Metode Importance Performance Analysis. UPT Perpustakaan ISI. Yogyakarta.

Fuad, Iwan Zaenul; Aenurofik; Ahmad Rosyid. 2015. Belenggu Tengkulak Atas Petani Pembudidaya Lele: Relasi Patron-Klien Budidaya Lele Di Wonotunggal Jawa Tengah, Jurnal Hukum Islam. 13(2):88 - 98. Pekalongan.

Hutabarat, Hermanto. 2013. Analisis Faktor-faktor Yang Mempengaruhi Petani Dalam Penjualan Padi Ke Tengkulak Di Kecamatan Jatilawang Kabupaten Banyumas. Jurnal Agritech. 15(2) : 87 - 104.
Irawan, Andri dan Evi Fitriani Komara. 2017. Pengukuran Tingkat Kepuasan Masyarakat Terhadap Pelayanan Pemerintahan Kecamatan Ketapang Kabupaten Bandung. Jurnal Inspirasi Bisnis dan Manajemen. 1(2). Universitas Swadaya Gunung Jati.

Megasari, Lutfi Apreliana. 2018. Ketergantungan Petani Terhadap Tengkulak Sebagai Patron Dalam Kegiatan Proses Produksi Pertanian (Studi Di Desa Baye Kecamatan Kayen Kidul Kabupaten Kediri). Departemen Sosiologi Universitas Airlangga. Surabaya.

Patiwiri, A.W. 2006. Teknologi Penggilingan Padi. Gramedia Pustaka Utama. Jakarta.

Permentan. 2017. Peraturan Menteri Pertanian Republik Indonesia No. 31/Permentan/PP.130/8/2017 tentang Kelas Mutu Beras.

Setiawati, Lenny dan Toto Sugiharto. 2008. Analisis Tingkat Kepentingan dan Kinerja Layanan Automated Teller Machine Bank Mandiri. Jurnal Ekonomi Bisnis. 13(3) Universitas Gunadarma. Jakarta.

Tjiptono, Fandy. dan Gregorius Chandra. 2000. Manajemen Jasa. Andi Offset, Service, Quality and Satisfaction. Yogyakarta.

Wibowo. 2007. Manajemen Kinerja. Edisi III. P.T. Raja Grafindo Prasada. Jakarta 